\title{
Impact of Temperatures During Fruit Development on Fruit Growth Rate and Qualities of 'KU-PP2' Peach
}

\author{
Panawat Sikhandakasmita*, Ikuo Kataoka, Ryosuke Mochioka and Kenji Beppu \\ Graduate School of Agriculture, Kagawa University, Miki, Kagawa 761-0795, Japan
}

In protected agriculture, optimum temperature management is crucial for enhancing fruit productivity and maintaining cost-effective production. The aim of the present study was to investigate the effects of temperature on peach fruit development and quality. Container-grown 'KU-PP2' peach trees grafted on low-chill peach rootstocks were cultivated under controlled conditions at different temperatures (20, 25, and $\left.30^{\circ} \mathrm{C}\right)$ during fruit development for two years $(2020$ and 2021). Fruit growth rates were calculated by measuring fruit diameter every $3 \mathrm{~d}$ from fruit setting to first harvest; fruit quality and phytochemistry were analyzed at harvest. Growing temperature markedly affected fruit growth, maturation, and fruit quality. The development of fruit in all treatments exhibited double sigmoid growth curves that included three stages ( $\mathrm{S} 1$, S2, and S3). Fruit growth rate during S1 and S2 stages was increased, and fruit development period was significantly shortened with an increase in temperature. Contrary to the duration of S3, which was longer at higher temperatures, fruit grown at a high temperature $\left(30^{\circ} \mathrm{C}\right)$ ripened by $12-18$ days earlier than those grown at low-temperature regimes. In addition, high-temperature conditions were also associated with reduced fruit quality (size, weight, and sweetness), but enhanced development of red coloration. Therefore, even though high-temperature conditions can accelerate early fruit expansion and hasten fruit maturity, such conditions also have negative effects on important agronomic fruit traits.

Key Words: forcing culture, low-chill peach, protected agriculture, Prunus persica.

\section{Introduction}

Temperature is considered the most influential of the environmental factors that affect fruit development (Menzel, 2019). In warm conditions, the fruit development period was short, with accelerated progress from flowering to fruit maturation. Warrington et al. (1999) reported a strong positive relationship between temperature and fruit expansion rate in apple, with fruits growing almost 10 times faster at $20^{\circ} \mathrm{C}$ than at $6^{\circ} \mathrm{C}$. Similar results were reported by Dela Bruna (2007), who studied the development of peach fruits in a subtropical region of Brazil. Even though temperature is clearly associated with fruit development, the effects of high temperature on fruit growth seem to depend on the timing and duration of exposure (Warrington et al., 1999).

Temperature was also reported to affect the maturity

Received; September 21, 2021. Accepted; October 31, 2021. First Published Online in J-STAGE on January 6, 2022.

This work was supported by JSPS KAKENHI Grant Number $18 \mathrm{~K} 05621$.

* Corresponding author (E-mail: panawat.sik@gmail.com). and phytochemistry of fruit crops, including apple (Austin et al., 1999; Sugiura et al., 2013), apricot (Brown, 1952), and peach (Weinberg, 1948). In spring 2004, for example, high temperatures in California were associated with small and early peach crops (DeJong, 2005). Mackenzie et al. (2011) reported that high temperatures negatively affect important agronomic fruit traits (size and weight) by disrupting normal plant functions and by reducing sugar accumulation. Similar results were reported for strawberry, in which fruit weight decreased as mean greenhouse temperature increased from 15 to $25^{\circ} \mathrm{C}$ (Kumakura and Shishido, 1994). Even though many studies have investigated the association between temperature and fruit productivity, few have investigated the influence of temperature on low-chill peaches under forcing conditions.

When growing fruit trees under forcing conditions, proper temperatures, during any plant development period are crucial for maximizing yield and preventing excessive energy use. 'KU-PP2' is a new yellow flesh peach cultivar with a low chilling requirement and early ripening that has been bred and released by Kagawa University, Japan, for use in forcing culture systems to 
produce very early season fresh peaches when the open field grown fruits are limited or not yet available. 'KU-PP2' requires approximately 400 chilling hours to flower and grow normally. Under natural conditions in Kagawa Prefecture, Japan, this cultivar blooms in mid to late March and ripens in mid to late June (Manabe et al., 2015). To maximize fruit productivity and minimize production cost, the responses of 'KU-PP2' peach trees to temperature must be established and considered during each development period. The effects of forcing temperature on the budburst, flowering, and carbon assimilation of 'KU-PP2' were reported previously (Sikhandakasmita et al., 2021a, b). However, the effects of temperature on fruit growth have yet to be fully explored. Therefore, the aim of the present study was to quantify the effects of temperature, during fruit development of 'KU-PP2' peach on fruit growth rate and qualities under controlled conditions.

\section{Materials and Methods}

\section{Plant materials}

The controlled conditions were conducted within three phytotrons located at the Faculty of Agriculture, Kagawa University, Japan ( $\left.34^{\circ} 15^{\prime} \mathrm{N}, 134^{\circ} 07^{\prime} \mathrm{E}\right)$. The air temperature in each phytotron was fixed at 20, 25, and $30^{\circ} \mathrm{C}$. 'KU-PP2' peach trees grafted on 'Tsukuba 1 Gou' peach rootstock were grown in $56 \mathrm{~L}$ containers. Six vigorous and uniform seven-year-old trees were used as plant materials and exposed to natural conditions prior to the temperature treatments. All 'KU-PP2' flowers were hand-pollinated in late March of both years using fresh pollen to synchronize fruit setting. After fruit set, two plants were moved into each phytotron, and the fruits thinned to 6-7 fruits per tree. All plants were maintained using the same cultural practices.

\section{Fruit development observation}

In both 2020 and 2021, five fruits were tagged on each tree, and the cheek diameter of each fruit was measured every $3 \mathrm{~d}$ using a digital vernier caliper. Absolute fruit growth rates $\left(\mathrm{mm} \cdot \mathrm{d}^{-1}\right)$ were calculated from fruit setting until fruit harvest. Fruit development period was computed as the number of days from flower blooming to fruit harvest.

\section{Fruit quality evaluation}

Fruits were harvested when fruit began softening and was easily detached. The dimensions (fruit length, cheek diameter, and suture diameter), fresh weight, and phytochemical components of fruit were measured immediately after harvesting. Total soluble solids concentration (TSS) was quantified on the cheeks of opposite sides of each fruit using PR-101 $\alpha$, a digital refractometer (Atago Co., Ltd., Japan), as well as flesh firmness. Fruit skins on the two opposite sides were removed before flesh firmness measurement. Firmness was determined with a KM-1 fruit hardness tester (Fujiwara Scientific Co., Ltd., Japan) equipped with a 5 -mm cylindrical flat probe, which was injected $10 \mathrm{~mm}$ into the flesh. The titratable acid (TA) content (\% malic acid) of each fruit was measured by extracting juice from the fruit pulp and titrating the juice using $\mathrm{NaOH}$ and an acidity titrator (TA-72; DKK-TOA Corporation, Japan). Finally, fruit skin coloration was scored visually as the percentage of skin with red coloration, according to the European cooperative programme for plant genetic resources (ECPGR) priority descriptors for peach (Giovannini et al., 2013).

\section{Data analysis}

Mean values were calculated for the quality data from each tree, and analysis of variance (ANOVA) of the quality data was performed using the Statistical Analysis System (SAS) University Edition (SAS Institute Inc., USA). Tukey's honestly significant difference (HSD) test was then used to identify significant differences among treatment means $(P<0.05)$. Within each treatment regime, mean values were also calculated for the fruit growth rates of each developmental stage, log-transformed, and then examined using a general linear model (GLM).

\section{Results and Discussion}

\section{Effect of temperature on fruit development and fruit maturation}

Growth temperature significantly affected the period of fruit development and timing of maturity. However, the fruit development pattern as a double sigmoid curve, which was partitioned into three stages (S1, S2, and S3), was observed in all temperatures (Fig. 1). Each fruit development stage was determined by fruit growth rate. During the S1 stage, 'KU-PP2' peach fruits exhibited rapid fruit expansion, whereas the S2 stage was characterized by limited fruit expansion, and the S3 stage was characterized by another period of rapid fruit expansion (Fig. 1).

Even though the double sigmoid growth pattern was observed in all the temperature regimes, the duration and growth rate for each stage varied. At higher temperature conditions $\left(25^{\circ} \mathrm{C}\right.$ and $\left.30^{\circ} \mathrm{C}\right)$, both the $\mathrm{S} 1$ and $\mathrm{S} 2$ stages were shorter, as was the duration of fruit maturation (Table 1). The $\mathrm{S} 1$ stage was shortest at $30^{\circ} \mathrm{C}$ (18-24 d), followed by $25^{\circ} \mathrm{C}(24-30 \mathrm{~d})$ and $20^{\circ} \mathrm{C}(30$ $36 \mathrm{~d}$; Table 1). However, the $\mathrm{S} 3$ stage was the longest at $25^{\circ} \mathrm{C}$ and $30^{\circ} \mathrm{C}$. Similar results in Japanese apricot (Yamamoto et al., 1990; Suzuki et al., 1995) and grape (Hale and Buttrose, 1974) showed that, even though high temperatures shorten the duration of fruit development in early-stages (S1 and S2), the conditions prolong the S3 stage.

There was a positive relationship between temperature and fruit growth rate during early fruit development (S1 and S2; Fig. 2). However, the relationship 
between fruit growth rate and temperature was greater during the $\mathrm{S} 1$ stage $(R=0.8722 ; P<0.001)$ than during the S2 stage $(R=0.4504 ; P=0.017)$. Higher temperatures accelerated early fruit growth but also retarded late fruit expansion. There was a strong negative relationship $(R=0.809 ; P<0.001)$ between temperature and fruit growth rate during the S3 stage (Fig. 2; Table 1). Furthermore, the elevated temperature shortened the S1 and S2 stages, thereby reducing the fruit develop-
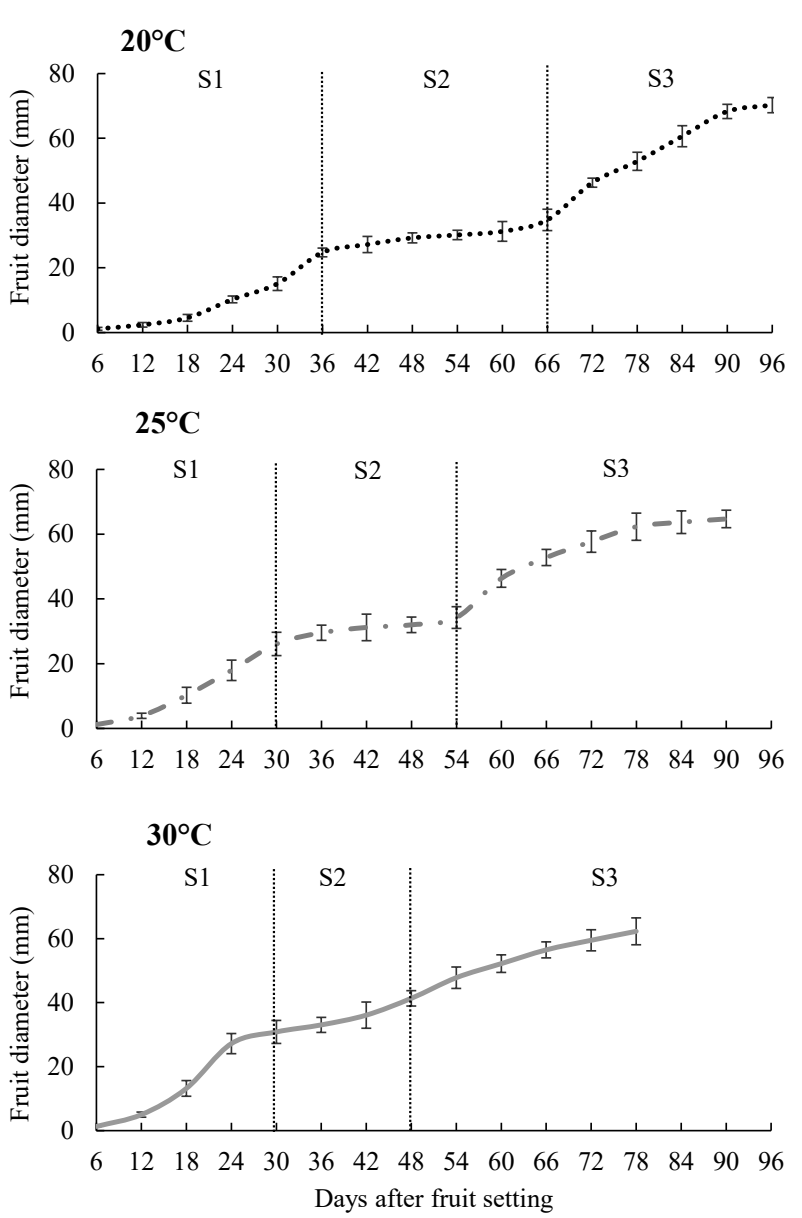

Fig. 1. Effect of temperature on the fruit growth of 'KU-PP2' peach. Fruit growth was measured from flower blooming to fruit harvest. All curves were divided in to 3 stages: S1, S2, and S3, by 2 vertical lines. ment period (Table 1). The shortest time span of the early fruit growth stage (S1) occurred at $30^{\circ} \mathrm{C}$ treatment, as did the shortest fruit development period $(78 \mathrm{~d}$; Table 1).

In the present study, the fruit development period of the 'KU-PP2' peach was shortened by high-temperature conditions. This corroborates the findings of Dela Bruna (2007), who reported that peaches cultivated in subtropical areas also respond to high-temperature con-
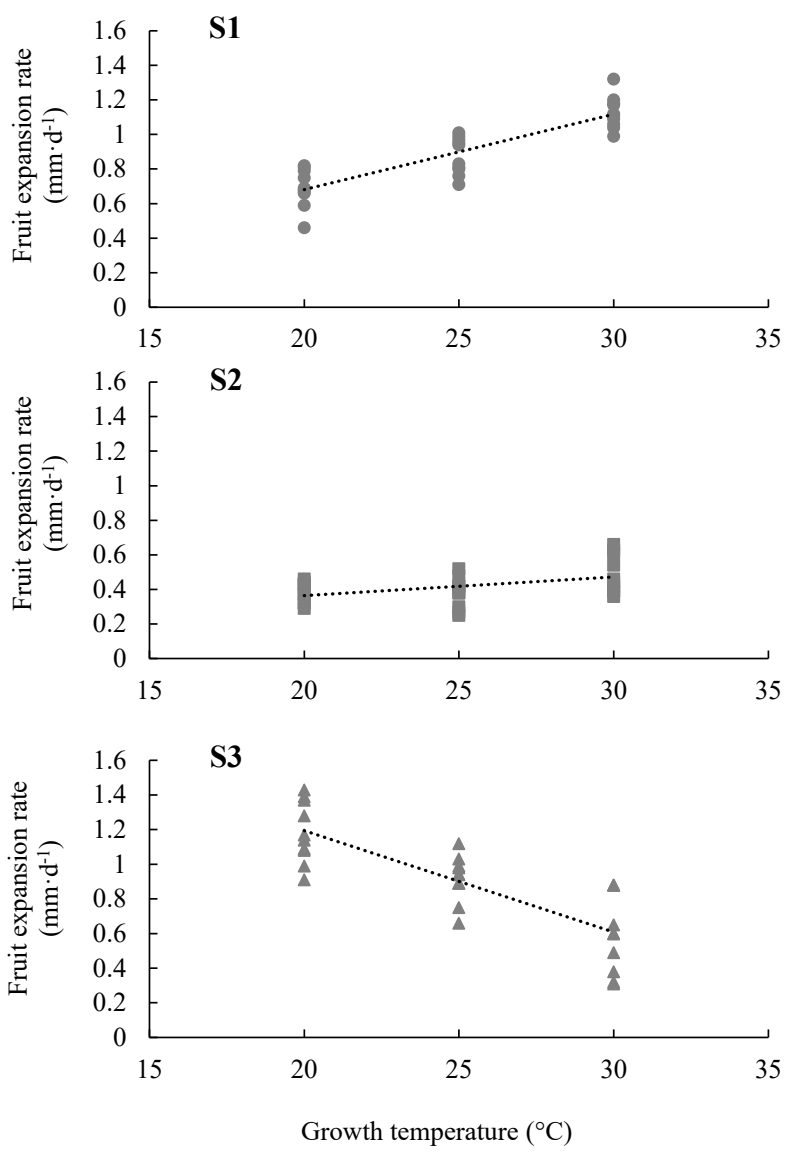

Fig. 2. Effect of growth temperature (GT) on the fruit expansion rate (FER) of 'KU-PP2' peach. Regressions for the S1, S2, and S3 fruit development stages were $\mathrm{FER}_{\mathrm{S} 1}=(0.0436 \times \mathrm{GT})-$ $0.191(R=0.8722 ; \mathrm{n}=30 ; P<0.001), \mathrm{FER}_{\mathrm{S} 2}=(0.0108 \times \mathrm{GT})$ $+0.148(R=0.4504 ; \mathrm{n}=30 ; P=0.017)$, and $\mathrm{FER}_{\mathrm{S} 3}=(-0.0586$

$\times \mathrm{GT})+2.366(R=0.809 ; \mathrm{n}=30 ; P<0.001)$, respectively.

Table 1. Effect of temperature on the phenology of fruit development in 'KU-PP2' peach.

\begin{tabular}{|c|c|c|c|c|c|c|}
\hline \multirow{2}{*}{ Temperatures } & \multicolumn{4}{|c|}{ Development stage duration $(\mathrm{d})^{\mathrm{z}}$} & \multicolumn{2}{|c|}{ Harvest date ${ }^{\mathrm{y}}$} \\
\hline & S1 & S2 & S3 & Total & 2020 & 2021 \\
\hline $20^{\circ} \mathrm{C}$ & $36 \mathrm{a}$ & $30 \mathrm{a}$ & $30 \mathrm{~b}$ & 96 a & 9 Jun (161) & 21 June (172) \\
\hline $25^{\circ} \mathrm{C}$ & $30 \mathrm{~b}$ & $24 \mathrm{~b}$ & $36 \mathrm{a}$ & $90 \mathrm{~b}$ & 31 May (152) & 14 June (165) \\
\hline $30^{\circ} \mathrm{C}$ & $24 \mathrm{c}$ & $18 \mathrm{c}$ & $36 \mathrm{a}$ & $78 \mathrm{c}$ & 24 May (145) & 4 June (155) \\
\hline$P$-value & $<0.001$ & $<0.001$ & 0.006 & 0.002 & - & - \\
\hline
\end{tabular}

Data was $\log$ transformed before statistical analysis.

${ }^{\mathrm{z}}$ Data are expressed as mean values \pm standard errors $(\mathrm{n}=20)$. Different lowercase letters within the same row denote significant differences $(P \leq 0.05$; Tukey's test $)$.

${ }^{y}$ Harvest date was defined as the date of first harvest. Values in parentheses indicate Julian calendar harvest dates. 
ditions by exhibiting accelerated growth during the fruit development period, resulting in early fruit ripening and small fruit size. Sugiura et al. (2003) and Hayama et al. (2007) reported that temperature was related to fruit growth and maturity in high-chill peaches and apples. Previous studies of peaches have reported that final fruit size is a function of cell division during the S1 stage and cell expansion during the S3 stage. Scorza et al. (1991) confirmed that cell number and size are directly related to final peach fruit size, since peach cultivar with small fruit exhibit shorter S1 and S3 stages. Furthermore, Yamaguchi et al. (2004) showed that cell division, cell enlargement and the final fruit size were influenced by genetic and environmental factors during fruit development. Sugiura et al. (2003) and Giovannelli et al. (2014) found positive relationships between the fruit size, weight, and fruit development period of apples and peaches, respectively. Therefore, long-term exposure to high temperatures during fruit development might reduce fruit size by hastening fruit growth during early fruit growth and by shortening the overall development period.

\section{Effect of temperature on fruit characteristics and phyto- chemical components}

A previous study with the 'KU-PP2' peach reported that exposure to high-temperature conditions negatively affected fruit productivity and quality (Sikhandakasmita et al., 2021b), and the present study confirms that fruit weight, fruit dimensions, and TSS were lowest at $30^{\circ} \mathrm{C}$ and greatest at $20^{\circ} \mathrm{C}$ (Table 2). The smaller size and TSS of 'KU-PP2' fruits grown under high-temperature conditions may be associated with the negative effects of high temperature on photosynthesis ability. Most of the raw materials and energy used for fruit growth are produced via photosynthesis. Sikhandakasmita et al. (2021b) reported that long-term exposure to hightemperature conditions reduced the photosynthesis ability of 'KU-PP2' peach trees by changing leaf characteristics, breaking photosynthetic pigments, and disrupting gas exchange and that this, ultimately, reduced fruit size and fruit quality. Lopez and DeJong (2007) confirmed that the occurrence of elevated temperature during fruit growth increases the risk of insufficient nutritional resources, resulting in poor fruit quality. However, in the present study, the temperature regime had no significant effect on fruit shape, flesh firmness, or titratable acidity (TA).

Regarding the effect of high temperatures on fruit development, high-temperature conditions significantly decreased not only the duration of the S1 stage and overall fruit development but also the final fruit size. Conversely, the conditions extended the period of the S3 stage. A longer period S3 stage due to hightemperature conditions did not increase final fruit size. These results suggest that the final fruit size was affected more greatly by cell division during the S1 stage than cell elongation during the S3 stage.

Even though exposure to high-temperature conditions during fruit development negatively affected the fruit quality of 'KU-PP2' peach, the elevated temperature also stimulated the development of red coloration on the fruits' skin (Table 2). Fruit grown at $30^{\circ} \mathrm{C}$ had more red coloration than fruit grown at lower temperature regimes. Many studies have reported that extent of red coloration on peach skin is positively related to light exposure (Corelli-Grappadelli and Coston, 1991; Kataoka and Beppu, 2004). Therefore, peach fruits ripened under shade or low-light conditions possess less red coloration than fruit ripened under full sunlight. Furthermore, a previous study of 'KU-PP2' peach reported that 'KU-PP2' trees grown at $30^{\circ} \mathrm{C}$ had smaller leaves, which reduced the level of canopy shade. As a result, peach fruit grown under hightemperature conditions were probably exposed to higher light intensities, which may be associated with greater red skin coloration (Sikhandakasmita et al., 2021b).

\section{Conclusions}

In the present study, growing temperatures significantly affected the development period, agronomic

Table 2. Effect of temperature on the fruit characteristics of 'KU-PP2' peach.

\begin{tabular}{|c|c|c|c|c|}
\hline \multirow{2}{*}{ Fruit trait } & \multicolumn{3}{|c|}{ Temperatures $^{\mathrm{z}}$} & \multirow{2}{*}{$P$-value } \\
\hline & $20^{\circ} \mathrm{C}$ & $25^{\circ} \mathrm{C}$ & $30^{\circ} \mathrm{C}$ & \\
\hline Fruit weight (g) & $137.5 \pm 4.9 \mathrm{a}$ & $124.5 \pm 3.1 \mathrm{~b}$ & $98.0 \pm 2.5 \mathrm{c}$ & $<0.001$ \\
\hline Fruit cheek diameter (mm) & $55.7 \pm 2.6 \mathrm{a}$ & $50.3 \pm 1.4 \mathrm{~b}$ & $47.4 \pm 2.2 \mathrm{c}$ & $<0.001$ \\
\hline Fruit suture diameter $(\mathrm{mm})$ & $58.1 \pm 2.4 \mathrm{a}$ & $52.2 \pm 1.1 \mathrm{~b}$ & $51.7 \pm 2.7 \mathrm{~b}$ & 0.015 \\
\hline Fruit length $(\mathrm{mm})$ & $56.5 \pm 2.2 \mathrm{a}$ & $54.8 \pm 1.2 \mathrm{ab}$ & $51.6 \pm 3.3 \mathrm{~b}$ & 0.021 \\
\hline Total soluble solids ( $\left.{ }^{\circ} \mathrm{Brix}\right)$ & $15.8 \pm 0.4 \mathrm{a}$ & $12.0 \pm 0.3 \mathrm{~b}$ & $11.7 \pm 0.5 \mathrm{~b}$ & 0.038 \\
\hline Titratable acidity (\%) & $0.23 \pm 0.05$ & $0.19 \pm 0.02$ & $0.22 \pm 0.06$ & 0.434 \\
\hline Flesh firmness $(\mathrm{N})$ & $3.34 \pm 0.11$ & $3.63 \pm 0.08$ & $3.53 \pm 0.13$ & 0.365 \\
\hline Red coloration (\% surface) & $10-15 \mathrm{~b}$ & $10-15 \mathrm{~b}$ & $60-75$ a & $<0.001$ \\
\hline
\end{tabular}

\footnotetext{
z Data were expressed as mean \pm standard errors $(n=20)$. Different lowercase letters within the same row denote significant differences $(P \leq 0.05$; Tukey's test).
} 
characteristics, and phytochemical components of 'KU-PP2' peach fruit. High-temperature conditions can accelerate early fruit growth and fruit maturity and can stimulate the development of red skin coloration in 'KU-PP2' peach; however, such conditions can also retard late fruit development and negatively affect aspects of fruit quality. Thus, identifying the proper temperature for each fruit development phase is crucial to maximizing fruit productivity and maintaining the economic value of peach fruit produced by protected agriculture.

\section{Literature Cited}

Austin, P. T., J. Hall, P. W. Gandar, I. J. Warrington, T. A. Fulton and E. A. Hallingan. 1999. A compartment model of the effect of early-season temperatures on potential size and growth of 'Delicious' apple fruit. Ann. Bot. 83: 129-143.

Brown, D. S. 1952. Climate in relation to deciduous fruit production in California. V. The use of temperature records to predict the time of harvest of apricots. Proc. Amer. Soc. Hort. Sci. 60: 197-203.

Corelli-Grappadelli, L. and D. C. Coston. 1991. Thinning pattern and light environment in peach tree canopies influences fruit quality. HortScience 26: 1464-1466.

DeJong, T. M. 2005. Using physiological concepts to understand early spring temperature effects on fruit growth and anticipating fruit size problems at harvest. Summerfruit 7: 10-13.

Dela Bruna, E. 2007. Growth curve of peach fruits in subtropical environment. Rev. Bras. Frutic. 29: 685-689 (In Portuguese with English abstract).

Giovannelli, C., C. Bouzo, G. Ribero, D. Castro, N. Micheloud and N. Gariglio. 2014. External fruit quality and harvest time of low-chill peach and nectarine varieties at Santa Fe, Argentina. Aust. J. Basic Appl. Sci. 8: 427-433.

Giovannini, D., A. Liverani, D. Bassi and M. Lateur. 2013. ECPGR priority descriptors for peach [Prunus persica (L.) Batsch]. European Cooperative Programme for Plant Genetic Resources 1-30.

Hale, C. R. and M. S. Buttrose. 1974. Effect of temperature on ontogeny of berries of Vitis vinifera L. cv. Cabernet Sauvignon. J. Amer. Soc. Hort. Sci. 99: 390-394.

Hayama, H., O. Fujimaru, A. Iwatani, A. Ito, D. Sakamoto, S. Okada and Y. Kashimura. 2007. Influences of temperature during fruit growing season on fruit development of 'Akatsuki' peach. Hort. Res. (Japan) 6: 201-207 (In Japanese with English abstract).

Kataoka, I. and K. Beppu. 2004. UV irradiance increases development of red skin color and anthocyanins in 'Hakuho' peach. HortScience 39: 1234-1237.

Kumakura, H. and Y. Shishido. 1994. The effect of daytime, nighttime, and mean temperature on the growth of
'Morioka-16' strawberry fruits and plants. J. Japan. Soc. Hort. Sci. 62: 827-832.

Lopez, G. and T. M. DeJong. 2007. Spring temperatures have a major effect on early stages of peach fruit growth. J. Hort. Sci. Biotech. 82: 507-512.

Mackenzie, S. J., C. K. Chandler, T. Hasing and V. M. Whitaker. 2011. The role of temperature in the late-season decline in soluble solids content of strawberry fruit in a subtropical production system. HortScience 46: 1562-1566.

Manabe, T., K. Beppu and I. Kataoka. 2015. New lower-chilling peach cultivar with yellow flesh, 'KU-PP2'. Hort. Res. (Japan) 14 (Suppl. 1): 287 (In Japanese).

Menzel, C. M. 2019. Temperature has a greater effect on fruit growth than defoliation of fruit thinning in strawberries in the subtropics. Agriculture 9: 127. DOI: 10.3390/ agriculture9060127.

Sikhandakasmita, P., I. Kataoka, R. Mochioka and K. Beppu. 2021a. Chilling and heating accumulations impact bud burst and flowering of 'KU-PP2' peach tree. Acta Hortic. 1312: 211-218.

Sikhandakasmita, P., I. Kataoka, T. Ogata, R. Mochioka and K. Beppu. 2021b. Effect of growth temperature levels on photosynthetic ability and fruit quality of 'KU-PP2', a new lowchill peach cultivar. Adv. Hort. Sci. 35: 233-241.

Scorza, R., L. G. May, B. Purnell and B. Upchurch. 1991. Differences in number and area of mesocarp cells between smalland large fruited peach cultivars. J. Amer. Soc. Hort. Sci. 116: 861-864.

Sugiura, T., H. Ogawa, N. Fukuda and T. Moriguchi. 2013. Change in the taste and textural attributes of apples in response to climate change. Sci. Rep. 3: 2418. DOI: 10.1038/srep02418

Sugiura, T., N. Takada, H. Kuroda and H. Sugiura. 2003. Influence of temperature in young fruit stage on growth, development, and cell division of 'Hakuho' peach fruits. J. Japan. Soc. Hort. Sci. 72 (Suppl. 2): 340.

Suzuki, N., X. Wang and H. Inoue. 1995. Effects of temperature on fruit development in Japanese apricot cv. Nanko. Environ. Control. Biol. 33: 245-251.

Warrington, I. J., T. A. Fulton, E. A. Halligan and H. N. de Silva. 1999. Apple fruit growth and maturity are affected by early season temperatures. J. Amer. Soc. Hort. Sci. 124: 468-477.

Weinberg, J. H. 1948. Influence of temperature following bloom on fruit development period of 'Elberta' peach. Proc. Amer. Soc. Hort. Sci. 51: 175-178.

Yamaguchi, M., T. Haji and H. Yaegaki. 2004. Differences in mesocarp cell number, cell length, and occurrence of gumming in fruit of Japanese apricot (Prunus mume Sieb. et Zucc.) cultivars during their development. J. Japan. Soc. Hort. Sci. 73: 200-207.

Yamamoto, H., T. Watanabe and T. Miyahara. 1990. Fruit growth stages and forecasting of harvesting time in Japanese apricot. Agric. Hortic. 65: 45-52 (In Japanese). 